\title{
Власний досвід діагностики та лікування коронарно-серцевих фістул
}

\author{
Радченко М. П., Довгалюк А. А., Кузьменко Ю. Л., Максименко А. В., Руденко Н. М. \\ ДУ «Науково-практичний медичний центр дитячої кардіології та кардіохірургії МОЗ України» (Київ)
}

\begin{abstract}
Коронарно-серцеві фістули (КСФ) - вроджена патологія коронарного русла, яка проявляється патологічним з'єднанням між коронарними артеріями та камерами серця або судинами (верхня порожниста вена, легенева артерія або легеневі вени). За даними літератури, коронарно-серцеві фістули наявні у 0,002\% популяції і візуалізуються у 0,2-0,6\% пацієнтів, яким проводиться катетеризація порожнин серця. У роботі наведено результати 41 ендоваскулярного втручання у пацієнтів із коронарно-серцевими фістулами. Мета роботи - оцінити результати ендоваскулярних втручань у пацієнтів із коронарно-серцевими фістулами. Матеріали та методи. При підозрі на функціонування коронарно-серцевих фістул за даними ехокардіографії пацієнтам проводилося зондування порожнин серця із селективною коронарографією для підтвердження наявності, оцінки анатомічного відходження та гемодинамічної значущості КСФ, визначення показань до хірургічного або ендоваскулярного закриття патологічного сполучення. Результати та обговорення. Хірургічне або ендоваскулярне закриття гемодинамічно значущих КСФ було виконано у 5 пацієнтів, що становить 12,2\% від загальної кількості обстежених хворих. Після ендоваскулярного закриття КСФ ми не спостерігали тромбоемболічних ускладнень, ознак ішемії та міграції пристроїв для закриття фістул. Летальних випадків не було. Висновки. Зондування порожнин серця із селективною коронарографією є стандартом для діагностики коронарно-серцевих фістул і визначення лікувальної тактики.
\end{abstract}

Ключові слова: коронарно-серцеві фістули, ендоваскулярне втручання, вроджені вади серия, зондування порожнин серия.

Коронарно-серцеві фістули - вроджена патологія коронарного русла, яка проявляється патологічним з'єднанням між коронарними артеріями та камерами серця або судинами (верхня порожниста вена, легенева артерія або легеневі вени). Рідко може бути набутою патологією. За даними літератури, КСФ наявні у 0,002\% популяції і візуалізуються у 0,2-0,6\% пацієнтів, яким проводиться катетеризація порожнин серця [1, 3]. Ізольовано КСФ зустрічаються у 55-80\% випадках, а в поєднанні із вродженими вадами серця (ВВС) - у 20-40\% [3]. Коронарно-серцеві фістули анатомічно можуть відходити від правої та лівої коронарної артеpiї. Більшість уроджених фістул відходять від правої та передньої міжшлуночкової гілки лівої коронарної артерії. Фістули огинаючої гілки лівої коронарної артерії зустрічаються рідше. Більшість КСФ лишаються безсимптомними для пацієнтів, однак можуть приводити до значущого обкрадання коронарного кровотоку, ішемічних змін, інфаркту міокарда, застійної серцевої недостатності, інфекційного ендокардиту, порушень ритму та навіть раптової смерті $[2,4,6]$. Вперше коронарно-серцеві фістули описані німецьким анатомом В. Краузе у 1965 р., а в 1983 р. Рейді повідомив про перше закриття коронарної фістули за допомогою транскатетерного методу.

Мета роботи - оцінити результати ендоваскулярних втручань у пацієнтів з коронарно-серцевими фістулами.

Матеріали та методи. За період з 01.01.2013 р. по 31.12.2016 р. на базі ДУ «НПМЦДКМ МОЗ Украї- ни» було проведено 41 діагностичне ендоваскулярне втручання у пацієнтів із коронарно-серцевими фістулами. Всі інтервенційні втручання проводилися на ангіографах AXIOM ARTIS ZEE Siemens та AXIOM Artis BC.

При підозрі на функціонування коронарно-серцевих фістул за даними ехокардіографії пацієнтам проводилося зондування порожнин серця із селективною коронарографією для підтвердження наявності, оцінки анатомічного відходження та гемодинамічної значущості КСФ. Залежно від отриманих даних визначалися показання до хірургічного або ендоваскулярного лікування. Виняток становили пацієнти перших років життя: у таких пацієнтів необхідні дані можна отримати при проведенні аортографії. Вік пацієнтів склав від 0 днів до 36 років. Маса - від 2,3 до 90 кг, середня маса $-22,2 \pm 23,3$ кг. Із 41 пацієнта $19(46,3 \%)$ були чоловічої статі, $22(53,7 \%)$ - жіночої. В цю групу не ввійшли пацієнти похилого віку з ішемічною хворобою серця та пацієнти з атрезією легеневої артерії з інтактною міжшлуночковою перегородкою.

Результати та обговорення. Ізольовані КСФ було діагностовано у $21(51,2 \%)$ пацієнта, у $20(48,8 \%)$ пацієнтів КСФ поєднувалися з ВВС. У 12 пацієнтів в анамнезі були хірургічні або ендоваскулярні втручання $з$ приводу ВВС, у т. ч. в 1 хворого проведено хірургічне втручання з приводу ВВС з одномоментною перев'язкою фістули та у 1 - ендоваскулярне та хірургічне закриття КСФ. 

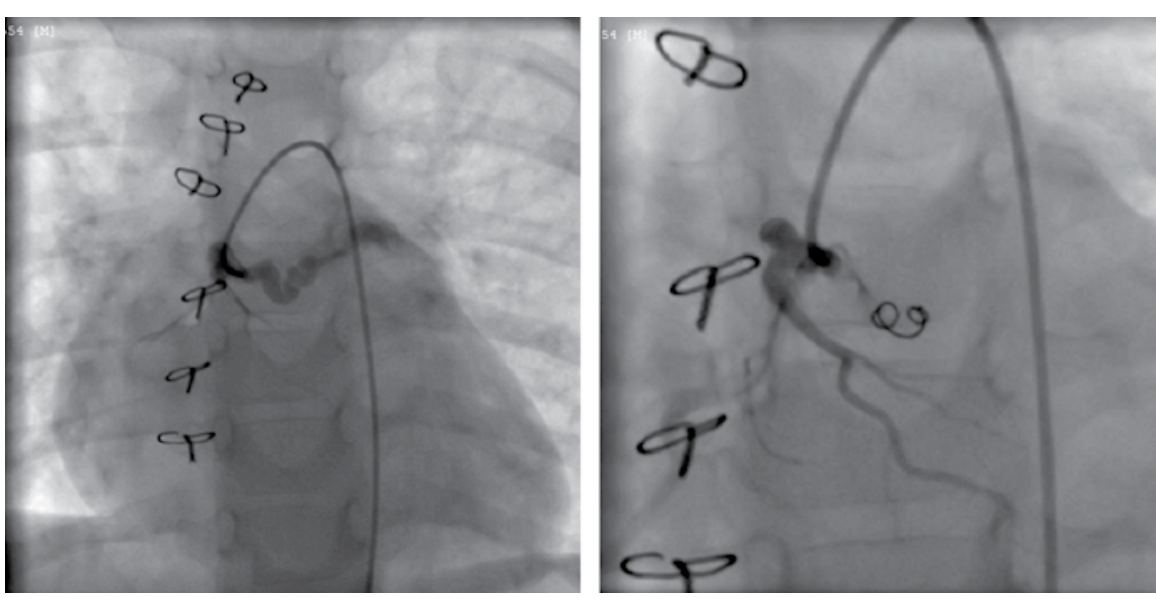

Рис. 1. Ендоваскулярне закриття КСФ між правою коронарною артерією та правим шлуночком. Пацієнт Н., 5 років, іст. хвороби № 554, 2015 р.

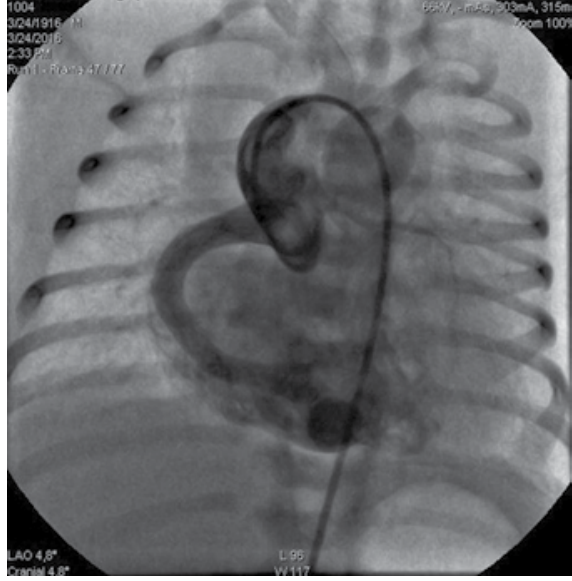

Рис. 2. Гемодинамічно значуща КСФ. Пацієнт Л., 1 доба, іст. хвороби № $1004,2016 p$.
В досліджуваній групі КСФ впадали в легеневу артерію - в $21(51,2 \%)$ випадку, у правий шлуночок - в 13 $(31,7 \%)$ випадках, у праве передсердя - в $6(14,6 \%)$, у ліве передсердя - в 1 (2,5\%) випадку. Розподіл анатомічних варіантів КСФ залежно від місця впадіння в нашій групі відповідав даним літератури [1, 3]. Слід зазначити, що у $36(87,8 \%)$ пацієнтів фістули були гемодинамічно не значущі. У таких пацієнтів діаметр фістули в місці відходження був менше 2 мм, відношення легеневого кровотоку до системного (Qp/Qs ) 1.5:1, відсутні ішемічні зміни на ЕКГ, негативний тредміл-тест з дозованим фізичним навантаженням (проводиться після 8-10 років). Таким пацієнтам не показана хірургічна корекція або ендоваскулярна емболізація коронарно-серцевої фістули і рекомендовано спостереження в динаміці з контролем ехокардіографії і ЕКГ 1 раз на рік.

Хірургічне або ендоваскулярне закриття КСФ показано пацієнтам з гемодинамічно значущими КСФ. У нашій групі таких пацієнтів було 5 (12,2\%). Трьом пацієнтам проведено ендоваскулярне закриття КСФ, 2 пацієнтам КСФ було перев'язано хірургічно. Ендоваскулярне закриття проводили за допомогою Embolization Coil COOK в одному випадку в пацієнта 3 коронарно-правопередсердною фістулою; 3 використанням PFM Nit-Occlud PDA 6x5 у пацієнта з решунтуванням КСФ після ендоваскулярного закриття та PFM Nit Occlud PDA 9х6 - в одному випадку після хірургічної перев'язки фістули. Усі пацієнти, в яких КСФ були закриті ендоваскулярно, приймали аспірин у дозі 5 мг/кг протягом 6 місяців.

Нижче наводимо ангіограму до та після ендоваскулярного закриття гемодинамічно значущої коронарносерцевої фістули у пацієнта після радикальної корекції ВВС - тетради Фалло в 2011 р. у віці 11 місяців (рис. 1).

Для прикладу наводимо ангіограму правокоронарно-правошлуночкової фістули у пацієнта, діагностова- ної в перший день життя та перев'язаної хірургічно на першу добу життя у 2016 р. (рис. 2).

Після ендоваскулярного закриття КСФ у 3 пацієнтів ми не спостерігали тромбоемболічних ускладнень, ознак ішемії та міграції пристроїв для закриття фістул. Летальних випадків не було.

Висновки. Зондування порожнин серця із селективною коронарографією є стандартом для діагностики коронарно-серцевих фістул та визначення лікувальної тактики.

\section{Література}

1. Chirantan V. Mangukia, MBBS. Coronary Artery Fistula // Ann Thorac Surg. - 2012. - Vol. 93. - P. 2084-92.

2. Dodge-Khatami A., Mavroudis C., Baker C. L. Congenital Heart Surgery Nomenclature and Database Project: anomalies of the coronary arteries // Ann Thorac Surg. 2000. - Vol. 69. - P. 270-97.

3. Percutaneous closure of congenital coronary artery fistulae: results and angiographic follow-up / Jama A., Barsoum M., Bjarnason H. et al. // JACC Cardiovasc Interv. - 2011. Vol. 4 (7). - P. 814-21.

4. Remodeling and thrombosis following closure of coronary artery fistula with review of management: large distal coronary artery fistula - to close or not to close? / Gowda S. T., Forbes T. J., Singh H. et al. // Catheter Cardiovasc Interv. - 2013. - Vol. 82. - P. 132-142. doi:10.1002/ccd.24699.

5. Late outcome of repair of congenital coronary artery fistulas - a word of caution / Said SM, Burkhart HM, Schaff HV et al. // J Thorac Cardiovasc Surg. - 2013. - Vol. 145. P. 455-460. doi: 10.1016/j.jtcvs.2012.11.028.

6. Coronary fistula between the left anterior descending coronary artery and the pulmonary artery: Two case reports / Mohamed F. Ibrahim, Sameh Sayed, Abdelfatah Elasfar et al. // J Saudi Heart Assoc. - 2012. - Vol. 24. P. 253-256. 


\title{
Our experience in diagnostics and treatment of coronary artery fistulae
}

\author{
Radchenko M. P., Dovgalyuk A. A., Kuzmenko Yu. L., Maksimenko A. V., Rudenko N. M. \\ Ukrainian Children's Cardiac Center (Kyiv)
}

Coronary artery fistulae (CAF) - congenital coronary pathology with abnormal connection between the coronary arteries and heart chambers or vessels (superior vena cava, pulmonary artery or pulmonary veins). In rare cases can be acquired pathology. According to statistics CAF is present in $0.002 \%$ of world population and diagnosed in $0,2-0,6 \%$ of patients during routine cardiac catheterization. This article contains data analysis of 41 cases of endovascular interventions in patients with coronary artery fistulae. Purpose. To evaluate results of endovascular interventions in patients with coronary artery fistulae. Materials and methods. Patients with echocardiography evidence of coronary-pulmonary fistulae underwent endovascular catheterization with selective coronary angiography for verification of anatomical type and hemodynamic significance. Depending on received data indications for surgical or endovascular treatment has been determined. No thromboembolic complications, signs of ischemia and occluding device migration, no mortality after endovascular CAF closure. Conclusions. Endovascular catheterization of cardiac chambers with selective coronarography is the method of choice in CAF diagnosis.

Key words: coronary artery fistulae, endovascular surgery, congenital heart defects, endovascular catheterization of cardiac chambers.

\section{Собственный опыт диагностики и лечения коронарно-сердечных фистул}

Радченко М. П., Довгалюк А. А., Кузьменко Ю. Л., Максименко А. В., Руденко Н. Н.

ГУ «Научно-практический медицинский центр детской кардиологии и кардиохирургии МЗ Украины» (Киев)

Коронарно-сердечные фистулы (КСФ) - врожденная патология коронарного русла, которая проявляется патологическим соединением между коронарными артериями и камерами сердца или сосудами (верхняя полая вена, легочная артерия или легочные вены). По данным литературы, коронарно-сердечные фистулы присутствуют у $0,002 \%$ популяции и визуализируются у $0,2-0,6 \%$ пациентов, которым проводится катетеризация полостей сердца. В работе приведены результаты 41 эндоваскулярного вмешательства у пациентов с коронарносердечными фистулами. Цель работы - оценить результаты эндоваскулярных вмешательств у пациентов с коронарно-сердечными фистулами. Материалы и методы. При подозрении на функционирование коронарносердечных фистул по данным эхокардиографии пациентам проводилось зондирование полостей сердца с селективной коронарографией для подтверждения наличия, оценки анатомического отхождения и гемодинамической значимости КСФ, определения показаний к хирургическому или эндоваскулярному закрытию патологического сообщения. Результаты и обсуждение. Хирургическое или эндоваскулярное закрытие гемодинамически значимых КСФ было выполнено у 5 пациентов, что составляет $12,2 \%$ общего количества обследованных больных. После эндоваскулярного закрытия КСФ мы не наблюдали тромбоэмболических осложнений, признаков ишемии и миграции устройств для закрытия фистул. Летальных исходов не было. Выводы. Зондирование полостей сердца с селективной коронарографией - стандарт для диагностики коронарно-сердечных фистул и определения лечебной тактики.

Ключевые слова: коронарно-сердечные фистулы, эндоваскулярное вмешательство, врожденные пороки сердиа, зондирование полостей сердиа. 